\title{
President's Page
}

Although the President of the American Name Society, because of the one-year term of office and the time lag in the publication of NAMES, cannot report activities in the year of incumbency, the Officers believe that reports of important meetings and other official matters should be given permanency by being published in NAMES. The following is an interim report by President (1983) Grace Alvarez-Altman.

At the suggestion of the President, an ad hoc committee on suggestions to improve the American Name Society and on revisions of the Constitution met from 12:30 p.m. to 2:00 p.m., May 7, 1983, at the Names Institute, Fairleigh Dickinson University, Madison, New Jersey.

Present were Grace Alvarez-Altman (Chair), E. Wallace McMullen, Leonard R.N. Ashley, Donald Orth, Allen Walker Read, and Kelsie Harder.

The basis for the special meeting was a letter sent by President AlvarezAltman to officers of the Society. Responding were John Algeo, Sterling Stoudemire, William G. Loy, Robert I. Alotta, John Allee, Wilber Zelinsky, Fred Robinson, Fred Tarpley, Grace Alvarez-Altman, Alan Rayburn, Frederic G. Cassidy, Mary R. Miller, Andre Lapierre, Leonard R.N. Ashley, Allen Walker Read and Sarah Jackson.

The following items and resolutions were considered and where necessary approved unanimously:

1. The Spring Number (1983) of the Onomastica Canadiana is to devote one page to the purpose, the research, and the publications of the American Name Society.

2. An information table for the American Name Society will be available each year in the exhibit hall of the Modern Language Association Convention. The Program Chairperson will be responsible for obtaining the space.

3. The office of the President will continue as a one-year term.

4. An attempt will be made to obtain or arrange a group rate flight (leaving either New York City or Washington, D.C.) to ICOS, Leipzig, August, 1984.

5. The Society will experiment with having two separate programs going at the same time during the MLA Convention period.

6. The following additions will be made to the By-Laws of the Constitution:

A. The First Vice. President will be in charge of the Annual Program. 
B. The Second Vice President will be Chairperson of the Membership Committee.

C. The Third Vice President will be the Public Relations Officer. 7. Concise details of the responsibilities of each of the American Name Society officers will be written into the By-Laws.

8. A copy of the Constitution and By-Laws will be given to each of the vice presidents immediately upon their assuming office.

9. The work on revision of the Constitution was tabled until the Executive Secretary has brought together all changes recorded in the minutes in past years. The revisions will be made during the calendar year 1984 and will be ready for the meeting of the Executive Committee at the Annual Meeting, 1984.

10. For the continuation of the American Name Society, stronger efforts must be made in maintaining membership, keeping current the files and financial records, responding to correspondence, producing information for the membership, and otherwise providing services that can be expected from an academic and scholarly organization.

Grace Alvarez-Altman

President, 1983

\section{Editor's Note}

With this issue, the Society welcomes its new Executive Secretary and Treasurer, Professor Wayne H. Finke, Baruch College. Dr. Finke brings to us a solid record of publication, administrative skills, fluent knowledge of the Romance languages, and, we can be assured, many future years of leadership in onomastics. He assumed his duties in August, 1983, but this is the first occasion we have had to list him among the officers.

He replaces Professor Murray Heller, who contributed dedicated service to the furthering of the study of names. Dr. Heller initiated the North East Names Institute, and many of us will always remember with gratitude and good feelings his gracious hosting at his beautiful home beside Turtle Pond, and also with academic gratitude his editing our too-often cluttered manuscripts for his handsomely printed Proceedings each year. Murray will continue to be active in the work of the Society. 